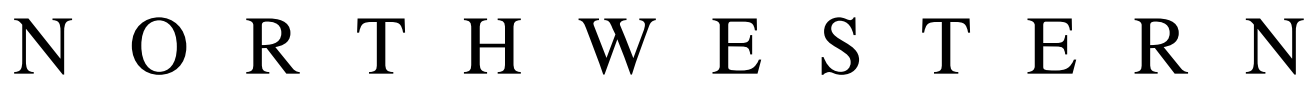 JOURNAL OF TECHNOLOGY A N D \\ INTELLECTUAL PROPERTY
}

\section{Trademark Dilution in Japan}

Kenneth L. Port

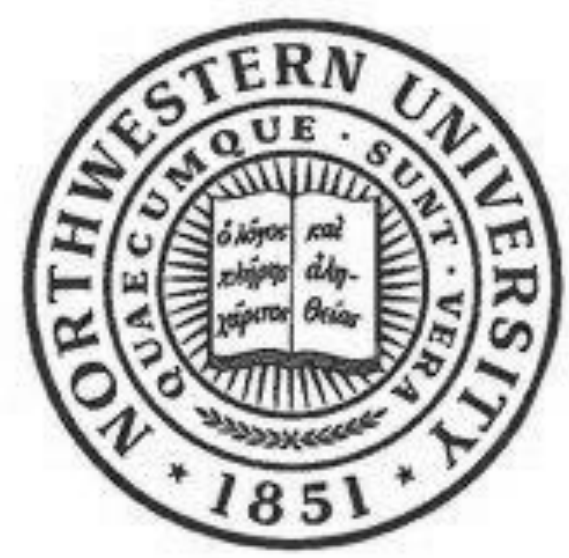




\title{
Trademark Dilution in Japan
}

\author{
Kenneth L. Port
}

\section{INTRODUCTION}

Trademark dilution is a right awarded to famous trademark holders to prevent the use of the same or similar marks on non-competing goods or services. ${ }^{1}$ Trademark infringement, in contrast, requires competition; if there is no competition between the parties, there can be no infringement. ${ }^{2}$ The concept of dilution was created to plug this "gap."3 That is, Kodak camera company could bring a suit for trademark dilution against a company making "Kodak" brand cameras, ${ }^{4}$ but such a suit would not doctrinally satisfy the requisite elements for trademark infringement because there would be no competition between a bicycle manufacturer and a camera manufacturer.

Japanese trademark dilution jurisprudence is in a state of confusion. In an otherwise highly rational, highly developed system, this scattered jurisprudence is unexpected. ${ }^{5}$ Perhaps the cause of action is still too new, ${ }^{6}$ or perhaps Japanese courts,

\footnotetext{
* Professor of Law and Director of Intellectual Property Law Studies, William Mitchell College of Law; J.D. University of Wisconsin. I am deeply indebted to the following people for their input on this article: Masako Yoshida, Laurie Sheen, and, most importantly, Toshiya Keneko. This article was prepared while I was Foreign Research Fellow at the Tokyo University's Business Law Center under the gracious auspices of Professor Nobuhiro Nakayama.

${ }^{1}$ David S. Welkowitz, Trademark Dilution 5 (2002) to source of definition. For purposes of this article, this shall be the definition of dilution.

${ }^{2} I d$. at 4.

3 See Frank I. Schechter, The Rational Basis of Trademark Protection, 40 HARV. L. REV. 813, 831 (1927).

${ }^{4}$ This has now become the ubiquitous trademark dilution example. It comes from the facts of an old trademark case from England. Eastman Kodak Co. v. Kodak Cycle Co., [1898] 15 R.P.C. 105 (High Ct. of Justice) (finding Kodak on bicycles lessened the distinctive capacity of Kodak on photographic supplies). This case has been relied upon by commentators to simply and easily crystallize the apparent problem that dilutive conduct raises. See, e.g., Monica Hof Wallace, Using the Past to Predict the Future: Refocusing the Analysis of a Federal Dilution Claim, 73 U. CIN. L. REV. 945, 947 (2005). A version of this idea, Kodak brand pianos, was even used in the legislative history of the United States Federal Trademark Dilution Act of 1996, codified at 15 U.S.C. § 1125(c) (2006). See H.R. REP. No. 104-374 (1995); see also Brief for Intellectual Property Law Professors as Amicus Curiae Supporting Respondents at 4, Moseley v. V Secret Catalogue, Inc., 537 U.S. 418 (2003)("If a company could sell bicycles under the Kodak name, surely another could sell pizza, another gloves, and still another desks. No longer could one refer to 'Kodak' without more. ...').

5 See, e.g., KENNETH L. PORT, JAPANESE TRADEMARK JURISPRUdENCE 1 (1998); Brent Yonehara, Landoftherisingsun.co.jp: A Review of Japan's Protection of Domain Names Against Cybersquatting, 43 IDEA 207, 212 (2003) ("The Trademark Law is a substantively modern statute. It provides for acquisition of trademark rights, trademark registration procedures, substantive trademark rights, and remedies for trademark infringement"); Masaya Suzuki, The Trademark Registration System in Japan: A Firsthand Review and Exposition, 5 MARQ. INTELl. Prop. L. REV. 133, 133 (2001) (“. . . an examination of Japanese trademark registration reveals layers of complexity”); Frank X. Curci, Protecting Your Intellectual Property Rights Overseas, 15 TRANSNAT'L LAw. 15 (2002); Masumi Anna Osaki, Comment, A Look at Damage Awards Under Japan's Trademark Law and Unfair Competition Prevention Law, 8 PAC. RIM. L. \& POL'Y J. 489 (1999) (arguing the Japanese system used to be imbued with particular Japanese cultural
} 
much like American courts, ${ }^{7}$ are reticent to recognize the full scope of the dilution right. It is more likely, however, that the confused status of Japanese trademark dilution law indicates a judiciary at odds with the legislature. This jurisprudence is not scattered because of a lack of technical skill by the judiciary, but to rein in a right the judiciary sees as inconsistent with the purposes of trademark protection in Japan.

The Japanese Legislature first recognized something resembling a dilution cause of action in 1993. In that year, the Japanese legislature ("Diet") amended the Unfair Competition Prevention Act (hereinafter "UCPA"). ${ }^{8}$ The two provisions of the UCPA that courts have used to deal with trademark dilution are as follows:

Article 2-1: As used in this Law, the term "unfair competition" shall mean:

(1) the act of using the Goods or Other Appellations ${ }^{9}$ (as used hereinafter, "Goods or Other Appellation" shall mean a name connected with a person's business, trade name, trademark, mark, the container or package of goods, or any other appellation of goods or businesses) which is identical with, or similar to, another party's Goods or Other Appellation that is well-known among the consumers, ${ }^{10} \ldots$ and causes confusion with the goods or business of that other party's.

(2) the act of using Goods or Other Appellations of another that are identical with, or similar to, another person's famous Goods or Other Appellations .... ${ }^{11}$

particularities but the times have changed and larger damage awards are now being granted to plaintiffs).

6 The new law took effect in 1993.

7 See, e.g., Robert N. Klieger, Trademark Dilution: The Whittling Away of the Rational Basis for Trademark Protection, 58 U. PITT. L. REV. 789, 841-51 (1997); Jacqueline A. Knapp, The Federal Trademark Dilution Act: The Circuit Split Makes a Desperate Call to the Supreme Court for Uniformity, 19 GA. ST. U. L. REV. 853, 889-91 (2003); Jonathan Mermin, Interpreting the Federal Trademark Dilution Act of 1995: The Logic of Actual Dilution Requirement, 42 B.C. L. REV. 207 (2000).

${ }^{8}$ Fusei kyoso boshiho [Unfair Competition Prevention Act], Law No. 47 of 1993, translated in EHS LAW BulL. SER. no. 6895 (1998) [hereinafter "UCPA"]. The original law is Fusei kyoso boshiho [Unfair Competition Prevention Act], Law No. 14 of 1934. The 1993 update was done so that Japan would be in compliance with the TRIPs Agreement signed in 1994. Agreement on Trade-Related Aspects of Intellectual Property Rights, Apr. 15, 1994, Annex 1C, 33 I.L.M. 1197 (1994). Article 16(3) of the TRIPs Agreement is said to be a dilution provision. See AKIRA OJIMA, CHIKUJO KAISETSU TRIPS KYOTEI [Clause by Clause EXPlanAtion OF THE TRIPs AgREEMENT] 89 (1999).

9 Many translate this word (hyoji) as "indication" rather than "appellation." See, e.g., CHRISTOPHER HEATH, THE SySTEM OF UNFAIR COMPETITION PREVENTION IN JAPAN 26-27 (2001). The Japanese word "hyoji" can also mean "expression." I think "appellation" is a more fitting translation, because that is the intent of the word. Either it acts as an appellation of source or not. Furthermore, "appellation" just seems more natural. Generally speaking, Americans speak of appellations of source, not indications of source. Additionally, an "indication" is what a thing might be; an "appellation" is what something might be called. As such, using "indication" here seems inappropriate. An alternative translation is "business designation." See Frank X. Curci \& Tamotsu Takura, Selected Aspects of Japanese Intellectual Property Law, 8 TRANSNAT'L LAW. 63, 84 (1995). The UCPA speaks only of "appellations" and not of "marks" or "trademarks." The reason for this is to clarify the distinction between "trademarks" (shyohyo), which by definition are registered, and non-registered indicators of source (hyoji or appellations).

${ }^{10}$ Here "the consumers" means "consumers that actually use the good or service."

${ }^{11}$ UCPA, Article 2.1. This and all translations of Japanese documents and cases in this article were done by the author. 
The most striking omission from these two statutory provisions is the word "dilution" (kishakuka) itself. Japan has no statute containing the term "dilution" that provides a cause of action for an owner of a famous trademark to prevent the subsequent use of that trademark on dissimilar goods in a non-competing manner. Therefore, although Japan is a civil law country, and courts must only apply the law as stated, rather than generate new options through their opinions, ${ }^{12}$ by definition any dilution case in Japan is judge-made law.

Although Article 2-1-2 of the UCPA is considered to be the "dilution" provision, not Article 2-1-1, ${ }^{13}$ in many important cases that reference dilution directly, courts rely on Article 2-1-1, and not Article 2-1-2. ${ }^{14}$ Article 2-1-1 of the UCPA has been broadly utilized to prevent the use of any well-known registered or unregistered appellations of source. ${ }^{15}$ Litigants have relied on it to prevent the use of everything from shelving shaped like a beehive ${ }^{16}$ to the importation of pharmaceuticals bearing the word VIAGRA. ${ }^{17}$ As such, it is also relied upon to prevent dilution. ${ }^{18}$

Japanese courts often do not make the critical distinction between a provision that requires a showing of confusion (Article 2-1-1) and one that does not (Article 2-1-2). ${ }^{19}$ Furthermore, Japanese courts do not distinguish between "causes confusion" and "an apprehension" of confusion. ${ }^{20}$

In the twelve years since inception of the UCPA, ${ }^{21}$ there have been relatively few reported decisions that squarely address dilution. ${ }^{22}$ In the same time period, there have

12 See generally Zentaro Kitagawa, Theory Perception - One Aspect of the Development of Japanese Civil Law Science (Ronald E. Lee trans.), in JAPANESE LAW AND LEGAL THEORY 3 (Koichiro Fujikura ed., 1996). See also Daniel H. Foote, Judicial Creation of Norms in Japanese Labor Law: Activism in the Service of - Stability?, 43 U.C.L.A. L. REV. 635 (1996); Daniel H. Foote, The Benevolent Paternalism of Japanese Criminal Justice, 80 CAL. L. REV. 317, 360 (1992).

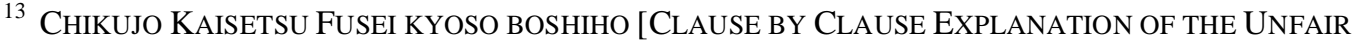
COMPETITION PREVENTION ACT] 45 (2003) [hereinafter "EXPLANATION OF THE UCPA"].

${ }^{14}$ See, e.g., Negurosu Denko K.K. v. Matsushita Denko K.K., 1819 HANREI JiHO 121 (Tokyo Koto Saibansho, May 31, 2002).

15 The Trademark Law, Law No. 127 of 1959, applies only to registered trademarks, not to general unregistered appellations of source, and has no language which might be extended to apply to dilution. The Japanese have elected to rely exclusively on the Unfair Competition Prevention Act to address dilution claims.

${ }^{16}$ K.K. Tying v. K.K. Zero First Design, 1833 HANREI Jiho 142 (Tokyo D. Ct., July 9, 2003).

17 Fizer Products, Inc. v. Yasuido Int'1, 1805 HANREI JiHo 140 (Tokyo D. Ct., Mar. 26, 2002).

18 Parfums Nina Ricci v. Madorasu K.K., 1040 HANREI TAimuZU 125 (Sup. Ct., July 11, 2000) (the "apprehension of confusion" envisioned in Article 4-1-5 of the Trademark Law is broad enough to include dilution-although not specifically relying on Article 2-1-2 of the UCPA).

19 This is similar to the United States where courts often require "confusion" before they will find dilution, even though confusion is not an element of the claim. See, e.g., Pharmacia Corp. v. Alcon Labs., Inc., 201 F. Supp. 2d 335 (D.N.J. 2002) (arguing no confusion, then handling the claim of dilution); Circuit City Stores, Inc. v. Office Max, Inc., 949 F. Supp. 409, 418 (E.D. Va. 1996) (asserting that confusion is not required to be found under the Dilution Act); PPG Indus., Inc. v. Clinical Data, Inc., 620 F. Supp. 604, 607 (D. Mass. 1985) (claiming that even though confusion is argued, it is not necessary for a dilution claim).

${ }^{20}$ An apprehension of confusion is close, but not exactly the same as, the "likelihood of confusion" standard used in the United States. See PorT, supra note 5, at 83. In the United States, we would call this issue actual confusion as compared to a likelihood of confusion.

21 The amended UCPA was passed on May 19, 1993.

22 As determined by searching http://legal.lexisnexis.jp (last visited Sept. 1, 2005). Also as determined by searching the Japanese Supreme Court web site at http://courts.co.jp (last visited Sept. 1, 2005). A 2002 study reports that there had been some forty-eight cases decided up to that time. Masaharu Miyawaki, 
been over 1,300 opinions issued regarding federal trademark dilution in the United States ${ }^{23}$ and countless other state court claims. That is, United States courts have been inundated with trademark dilution claims. This is not the case in Japan.

Why are there so few opinions in Japan? In a society with one half the population of the United States ${ }^{24}$ and the second largest economy in the world, ${ }^{25}$ would not one expect more trademark dilution cases?

The point of this article is to directly address this paucity of trademark dilution cases in Japan. This article concludes that first, there are more dilution cases brought in Japan than are reported (although that number is probably negligible). Second, because the UCPA is vague and does not even use the word "dilution," Japanese courts do not or cannot distinguish between fundamental elements of the cause of action. Third, the defensive trademark system, underutilized as it is, provides an alternative to dilution protection. Finally, the theoretical understanding of trademark law renders dilution claims superfluous. ${ }^{26}$

The result is that the dilution cause of action is very unsure in Japan. This lack of certainty may prevent some entities from recognizing and pursuing their rights under the statute. The confused state of Japanese dilution protection indicates that Japanese courts do not understand the cause of action or are reticent to apply it as it is written. Given the high degree of technical skill of Japanese judges,${ }^{27}$ it is not likely that they are simply making serious errors when applying dilution law to any given set of facts. Rather, it appears that Japanese judges have an inherent distrust of the notion of dilution. Japanese judges seem reluctant to apply the language as written and, instead, seek other options to attempt to confine the expansion of the trademark right.

\section{WHAT DILUTION STATUTE?}

The language of Article 2-1-1 of the UCPA is vague and broad, and clearly contemplates preventing the use of someone else's well-known appellation of source. As such, for both clauses 1 and 2 of Article 2-1 of the UCPA, the initial inquiry involves determining what an "appellation" is. Infringing use can take the form of any appellation of source; however, Japanese courts have yet to broaden the understanding of this

Expansion of the Scope of Protection Under Law of Business Symbols: Based on US Law Concerning Dilution, INST. OF INTELL. PROP., TOKYO, JAPAN, (2002). However, the number forty-eight is derived by counting all cases, even those that were subsequently appealed. Of those, seven were appealed to the relevant High Court. Therefore, in reality, this count should be forty-one. In addition, many of these fortyone cases mention dilution only in passing.

${ }^{23}$ Lexis search performed on or about May 23, 2005. Needless to say, that number would be quite a bit larger if you added all of the state dilution cases which did not rely on the Federal Trademark Dilution Act, 15 U.S.C. § 1125(c) (2006). (hereinafter "FTDA").

${ }^{24}$ Japan's 2005 population is about 127.4 million. DeP'T OF STATe, Bureau of East Asian AND PaC. AFFAIRS, BACKGROUND NOTE: JAPAN (Aug. 2005), at http://www.state.gov/r/pa/ei//bgn/4142/htm. (last visited Apr. 18, 2006) The United States' 2005 population is about 297.4 million. U.S. CENSUS BUREAU, ANNUAL POPULATION ESTIMATES 2000-2005 (Dec. 21, 2005), at http://www.census.gov/popest/states/NST-ann-est.html. (last visited Apr. 18, 2006).

${ }^{25}$ DEP'T OF STATE, BuREAu OF EAST Asian AND PAC. AFFAIRS, supra note 24 ("Japan's industrialized, free market economy is the second-largest in the world.").

${ }^{26}$ Kenneth L. Port, Protection of Famous Trademarks in the United States and Japan, 15 WIS. INT'L L.J. 259, 279 (1997).

27 JOHN OWEN HALEy, THE SPIRIT OF JAPANESE LAW 40 (1998). 
provision to sensory marks. ${ }^{28}$ Although the scent of thread was recognized as a valid and registrable trademark in the United States, it would not be possible to protect such indicators of source in Japan.

In the SEIROGAN TOI A case, ${ }^{29}$ the Osaka District Court concluded that each of the component parts of the name were common descriptive terms, but the combination of these terms, the long period of use, and the remarkable success of the product made it appropriate to call what the plaintiff had an "appellation" (hyoji). ${ }^{30}$

In another case, a middle school started using the term Aoyama Gakuin Chugakko to refer to its school. Aoyama Gakuin University is a Methodist college that started in Tokyo in $1874,{ }^{31}$ a mere six years after Japan was opened to the outside world. ${ }^{32}$ The middle school was enjoined from using that name after the college established that its name amounted to an "appellation" of source (hyoji). ${ }^{33}$ It is not surprising that this school was able to establish that their name was an appellation after 127 years of exclusive use.

The core of Article 2-1-1 seeks to prevent the use of a "well-known" (hiroku ninshikisareteiru) "good or other appellation" ("shohintohyoji") - either registered or unregistered. However, what constitutes a "good or other appellation" is not entirely apparent. It is clear that the statute contemplates a good itself as indicating source because it uses the term "shohintohyoji," which would literally be translated as "good or other appellation." On the other hand, the statute defines shohintohyoji in a parenthetical as "a name connected with a person's business, trade name, trademark, mark, the container or package of goods, or any other appellation of goods or businesses." Despite the implication of the word shohintohyoji, its given definition seems to preclude the protection of "goods" themselves unless the good in question is a "container or packaging of [other] goods.",34

Article 2-1-1 also requires the plaintiff to show actual confusion - "causes confusion" "kondowo shojisaseru." 35 In order for confusion to be established, the parties

\footnotetext{
${ }^{28}$ Registering and recognizing rights in sensory marks in the United States is now quite common. See, e.g., Nancy L. Clarke, Note, Issues in the Federal Registration of Flavors as Trademarks for Pharmaceutical Products, 1993 U. ILL. L. REV. 105 (1993); Faye M. Hammersley, The Smell of Success: Trade Dress Protection For Scent Marks, 2 MARQ. InTELL. PROP. L. REV. 105 (1998).

29 Taiko Pharmaceuticals, K.K. v. Nisshin Pharmaceuticals K.K., 1023 HANREI TAIMUZU 257 (Osaka D. Ct., Nov. 3, 1999) (holding that SEIROGAN TOI A, a sugar coated anti-diarrhea medicine, was famous). Seirogan claimed that soldiers used its anti-diarrhea medicine during the Russo-Japanese War (1904-05). Taiko still uses a trumpet, a symbol of charging troops, as its trademark for Seiro-gan. It used to use slightly different kanji characters for its name (pronounced the same way). The old characters meant "a pill to conquer Russia." Taiko changed Seirogan to the present characters in 1949, four years after World War II ended. See http://www.seirogan.co.jp/company/history.html.

30 Taiko Pharmaceuticals, 1023 HANREI TAIMUZU at 257.

31 See Aoyama Gakuin University, About the University, http://www.aoyama.ac.jp/en/outline/history.html (last visited Mar. 6, 2006).

${ }^{32}$ See Kenneth L. Port \& Gerald McAlinn, Comparative Law: LAw AND The Legal Process IN JAPAN 29-34 (2d ed. 2003).

33 Aoyama Gakuin v. Shimizugaoka Gakuen, 1815 HANREI JiHo 148 (Tokyo D. Ct., July 19, 2001).

34 See, e.g., [Parties Unnamed], 8 MutAI ReISHU 462 (Tokyo High Ct., Dec. 8, 1976) (butter container protected). But $c f$. K.K. Tsukuda Original v. K.K. Lana, 1781 HANREI JiHO 142 (Tokyo High Ct., Dec. 12, 2001) (Rubik's Cube is well-known for purposes of Article 2-1-1 of the UCPA and, as such, a protectable appellation).

35 "It is given that a prerequisite to establishing confusion as to business interests is the establishment
} 
must be in competition with each other. As such, it does not appear to be the appropriate provision for preventing dilution; however, as stated above, several courts have relied upon this provision. Article 2-1-2, a provision that allows the holder of a famous appellation of source to enforce that right against third parties regardless of competition, is a more appropriate provision to apply to a likely dilution setting. ${ }^{36}$

\section{A. The Evolution of Article 2-1-2:}

In 1992, the Japanese government commissioned a study of the need to have a "dilution-like" statute. It concluded as follows:

In the current information society, product or business appellations are being more broadly used via a variety of different media. These brand images are becoming well known. These independent brand images have specific customer appeal. As such, they have attained an independent value of their own. Through use of these famous appellations, for example even when there is no confusion, such a user can gain the customer appeal of this famous appellation even though he did nothing to achieve it. This is known as "free riding." As a result, consumers might become confused that this newcomer is the same as the company that endeavored to obtain high trust and repute. In this case, the good image of the firstcomer would be damaged. This is known as "dilution." [In such a case in the past,] courts have simply presumed confusion even though the facts of the case made confusion an impossibility. Judges have deemed such a conclusion to be appropriate; however, they have come to question the notion of presuming confusion. Therefore, frankly speaking, it is appropriate to create a new cause of action where confusion is not necessary in order to protect famous appellations. ${ }^{37}$

Several things become apparent from this summary. Most striking, of course, is that the contemplated dilution cause of action is somewhat different than the typical American notion of dilution, where actual harm must be shown to establish dilution when marks are not identical. ${ }^{38}$ Although brand identity is a growing phenomenon in Japan, it is certainly not the case that it did not exist prior to 1992, as the report of the intellectual property policy committee suggests. Nevertheless, in the United States, while brands might have an independent identity, they do not have an independent monetary value. ${ }^{39}$

that the parties were in competition." EXPLANATION OF THE UCPA, supra note 13, at 45. One way or the other, the objective of the 1993 amendments to the UCPA were to allow for the owner of a famous appellation to be able to get redress, regardless of his ability to establish confusion. Id. at 46.

36 EXPLANATION OF THE UCPA, supra note 13, at 45.

37 SANGyo Kozo SHINGIKAi CHITEKi ZAISAN SEISAKu BUKAi HoKOKUSHO [REPORT OF THE InTEllectual PROPERTy POLICY COMMITTEE OF THE INDUSTRIAL STRUCTURE COUNCIL] (1992).

38 See, e.g., Moseley v. V. Secret Catalogue, 537 U.S. 418 (2003).

39 This is sometimes referred to as the "Holmes/Hand Doctrine." See, e.g., Monsanto Chem. Co. v. Perfect Fit Prods. Mfg. Co., 349 F.2d 389 (2d Cir. 1965); Standard Brands, Inc. v. Smidler, 151 F.2d 34 (2d Cir. 1945); Industrial Rayon Corp. v. Duchess Underwear Corp., 92 F.2d 33 (2d Cir. 1937). See also Diane Martens Reed, Use of "Like/Love" Slogans in Advertising: Is the Trademark Owner Protected?, 26 SAN DiEgo L. REV. 101 (1989); Weiqui Long, Intellectual Prop. in China, 31 ST. MARY’s L.J. 63, 72 (1999). 
Trademarks themselves are not property in the American system, as such, they cannot have an "independent value." Any value a trademark has is directly tied to the goodwill behind the mark and thus can never be separated from that goodwill. ${ }^{40}$

Dilution is a cause of action somewhere between blurring and tarnishment. ${ }^{41}$ To find a party liable, this report would require that the "good image" of the first-comer actually be damaged somehow by the party engaged in dilution. Actual damage is required. This is also a distinction that seems lost on Japanese courts.

Article 2-1-2 is incredibly broad in its scope. Any use of anyone's famous good or other appellation, regardless of confusion and regardless of competition between the parties, creates a cause of action. To establish "dilution" under Article 2-1-2, the plaintiff must establish the following:

1. use of the plaintiff's goods or other appellation by the defendant;

2. the plaintiff's appellation is famous;

3. the defendant's appellation is the same or similar to the plaintiff' s. ${ }^{42}$

There appears to be little case law on the first element. ${ }^{43}$ Essentially, this element contemplates the obvious: that the defendant has to be using the plaintiff's appellation. This includes the possibility that the defendant may be using the appellation for something other than source denoting purposes. It is only the source-denoting purpose that is protected. ${ }^{44}$

\section{B. Appellation Fame}

Fame, on the other hand, deserves serious thought and attention, and Japanese courts have responded to this challenge. Fame becomes relevant due to another key distinction between Article 2-1-1 and Article 2-1-2. Article 2-1-1 applies to wellrecognized (hiroku ninshikisareteiru) goods or other appellations, while Article 2-1-2 applies only to famous (chomei) goods or other appellations. For an appellation to be

The doctrine is also clearly stated in the following cases: United Drug Co. v. Theodore Rectanus Co., 248 U.S. 90, 97 (1918) (asserting "there is no such thing as property in a trademark except as a right appurtenant to established business or trade in connection with which the mark is employed"); Thomas Kefoot \& Co. v. Louis K. Liggett Co., 59 F.2d 80, 90 (1932) (stating that a trademark does not create a monopoly in a "proper sense, but is merely a convenient means for facilitating the protection of one's good-will in trade. ..”); Brother Records, Inc. v. Jardine 318 F.3d 900, 906 (2003) (stating "the primary cost of recognizing property rights in trademarks is the removal of words . . from our language"). See also Kenneth Port, The 'Unnatural' Expansion of Trademark Rights: Is A Federal Dilution Statute Necessary?, 18 SETON HALl LeGIS. J. 433 (1994); Maya Alexandri, The International News QuasiProperty Paradigm and Trademark Incontestability: A Call for Rewriting the Lanham Act, 13 HARV. J.L. \& TECH. 303 (2000); Stacey L. Dogan \& Mark A. Lemley, Trademark and Consumer Search Costs on the Internet, 41 HoUS. L. REV. 777, 788 (2004) ("First and most generally, trademarks are not property in gross ...").

${ }^{40}$ If the report's intent is to end the bizarre Japanese judicial practice of recognizing confusion in the broad sense when the appellations are famous, but there is no confusion, this would be a good thing. See SHIGEHIKo KanAi, FuSEI KyOSO BoshiHo KomentARU [UNFAIR COMPETITION PREVENTION LAW AND COMMENTARY] 42 (2004). The Japanese judiciary has not apparently responded as such.

${ }^{41}$ Blurring refers to when a famous trademark is used in so many ways that the original source is not easily identifiable. Tarnishment occurs when someone uses a famous trademark on a shoddy or inferior product.

${ }^{42}$ See generally UCPA, Article 2.1.

43 See supra notes 26-28 and accompanying text.

44 EXPLANATION OF THE UCPA, supra note 13, at 46. 
well-known, it need not be known nationwide ${ }^{45}$ - simply being known by most people in one region of Japan will suffice. ${ }^{46}$ However, for a mark to be famous, and thus protected under Article 2-1-2, it generally needs to be known nationwide, such that even someone in a completely different market would recognize it. ${ }^{47}$

\section{Degree of Fame}

To determine how "famous" a mark must be to trigger Article 2-1-2, courts examine several elements. ${ }^{48}$ The first question involves the degree of fame. The second asks "for whom must the mark be famous?" This second question can be further broken down into questions of regional fame and field-specific fame. Shoen Ono describes the requirement that the appellation be famous in the following terms: "[t]o be famous, an appellation must achieve an exacting standard ... it must appear to be a striking or remarkable appellation." 49 Even though the degree of fame is supposed to be an exacting standard, ${ }^{50}$ if the appellation is famous enough, Japanese courts will presume confusion. ${ }^{51}$ In the Levi Strauss \& Co. v. K.K. Edwin Mfg., ${ }^{52}$ the court found that the fact that a mere $18.3 \%$ of respondents nationwide could correctly identify the stitching on the rear pockets of Levi's jeans was adequate to establish that the mark was famous. ${ }^{53}$ This decision begs the question that if $18.3 \%$ satisfies the test for a famous appellation, ${ }^{54}$ how exacting could the standard be? A clear declaration of the standard by the court would certainly be desirable. Given the status of dilution cases in Japan, however, this seems very far off indeed.

\section{Regional Fame}

Although the basic, black letter rule about fame for the purposes of Article 2-1-2 is that appellation must be nationally famous in Japan, ${ }^{55}$ some important commentators feel

\footnotetext{
45 See Curci \& Takura, supra note 9, at 84. Appellations which are widely recognized in countries outside of Japan may face special criteria for being recognized in Japan. See Curci, supra note 5, at 17 n.10, citing Japan Trademark Association, 5 JTA BULLETIN 3 (1998).

46 EXPLANATION OF THE UCPA, supra note 13, at 47.

${ }^{47}$ Fame (chomei) under the Trademark Law is interpreted the same. Therefore, when a mark had regional recognition but not nationwide fame, the mark is said not to be famous. See K.K. Tsuki Tomo no KaiMaruai K.K. v. K.K. Kyoto Nishikawa, 13 MutAi ReISHU 793 (Tokyo High Ct., Nov. 5, 1981). For examples of cases which found appellations to be famous, see Taiko Pharmaceuticals v. Nisshin Pharmaceuticals K.K., 1023 HANREI TAIMUZU 257 (Osaka D. Ct., Nov. 3, 1999) (Holding that SEIROGAN TOI A, a sugar coated anti-diarrhea medicine, is famous); Takeda Pharmaceuticals K.K. v. Toyo Farumer K.K., 1044 Hanrei TAimuZu 246 (Osaka D. Ct., Sept. 16, 1999) (Holding that ALINAMIN is famous as used on vitamin supplements and ALINABIG infringes).

48 See KANAI, supra note 40, at 45.

49 Shoen Ono, SHin CHuKai Fusei Kyoso Boshiho [NEW COMMENTARY ON THE Unfair COMPETITION PREVENTION ACT] 288 (2000).

50 See KANAI, supra note 40, at 45.

51 See infra note 58 and accompanying text.

521032 Hanrei TAimuZu 281 (Tokyo D. Ct., Dec. 6, 2000).

53 Id. at 290.

${ }^{54}$ E. I. DuPont de Nemours \& Co. v. Yoshida Intern., Inc., 393 F.Supp. 502, 526 n.54 (C.D.N.Y. 1975) (Stating that a survey conducted for litigation in the Teflon case in the United States showed that $6 \%$ of respondents thought "refrigerator" was a trademark).

${ }_{55}$ Tsuneyuki Yamamoto, YOSETSU FUSEI KYOSO BOSHIHO [Outline of the Unfair Competition
} 
differently. For example, if a product is used only in northern Japan, one could still consider its appellation as famous, depending upon the characteristics of the product and of the purchasers. ${ }^{56}$ There are others who feel that even though the appellation is not famous nationwide, as long as the defendant is using the same or similar appellation where it is famous, this use should suffice for the fame element. ${ }^{57}$ It is clear that the standard for fame for the purposes of Article 2-1-2 is quite high. Although there may be some narrow exceptions, nationwide fame is generally required.

\section{Field of Use of Fame}

Japanese commentators also discuss a "field of use" of fame. ${ }^{58}$ Under this theory, there are fields of use where an otherwise famous mark would not be famous. While this is directly inconsistent with the purpose of dilution prevention in the first place, there is case law to support this theory. For example, in K.K. Toraya v. K.K. Kurokawa, ${ }^{59}$ the plaintiff had used TORAYA on, or in connection with, many kinds of candies and bread. The defendant intended to use TORAYAKUROKAWA on or in connection with the manufacture and sale of Japanese sweet bean jelly, jewelry, textiles, and beauty salon massages. The court held that the plaintiff's appellation was famous in the field of sweets but not in other fields. ${ }^{60}$

Holdings that presume confusion even when there is no competition seem to weaken the fundamental purpose behind dilution protection in the first place: to prevent a non-competitor from using a famous appellation on a non-competing good or service. Taking these holdings on their face, it's not hard to see why dilution rationale has been unpopular in Japan.

\section{Additional Requirements}

There is some debate over what is required in addition to the level of fame an appellation must have before it is protected. ${ }^{61}$ Some argue that an exceedingly high brand identity is required. ${ }^{62}$ Tatsuki Shibuya lists the following as essential elements

\footnotetext{
Prevention Act] 113 (2002).

56 ONO, supra note 49, at 289. For example, northern Japan gets heavy snow in the winter. See The Natural World of Japan: The Climate of Japan, at http://www.seinangu.ac.jp/ djohnson/natural/climate.html (last visited Feb. 26, 2006). Okinawa, a tropical island in the Pacific Ocean and also part of Japan, the average temperature in January is 61.3 degrees. See Seasonal Averages, at http://www.shinryokan.com/e/news/weather.html (last visited Feb. 26, 2006). Therefore, winter wear would not be sold in Okinawa. If a manufacturer sold snowshoes, its appellation may become famous in Hokkaido but not in Okinawa. It would be unfair to the owner of that appellation for snowshoes to say that, by definition, it could not have a famous appellation. This is Ono's concern.

57 YOSHIYUKI TAMURA, FUSEI KYOSOHO GAISETSU [OUTLINE OF THE UNFAIR COMPETITION PREVENTION ACT] 243 (2003).

58 KANAI, supra note 40, at 47.

59 See K.K. Toraya v. K.K. Kurokawa Shoji, available at http://legal.lexisnexis.jp/jp/lngateway.dll?f=templates\&fn=defaultHome_JP.htm\&vid=Japan:10.1048/Enu (Tokyo D. Ct., Dec. 21, 2000).

${ }^{60}$ Injunction granted on other grounds. See id.

61 KANAI, supra note 40, at 47.

62 See Yамамото, supra note 55, at 113.
} 
required for protection: (1) specific distinctiveness; (2) fame; (3) very high quality goods or services; (4) unique positioning or status; and (5) abstract distinctiveness. ${ }^{63}$

It is difficult for Americans to conceive of the difference between "specific distinctiveness" and "abstract distinctiveness." Under American law, any "abstract" distinctiveness of an appellation of source is unprotectable; however, if you apply it to the traditional dilution rationale, it becomes a bit clearer. Specific distinctiveness is when you hear the word KODAK and know that the manufacturer of the goods or services has something to do with cameras. However, if the word KODAK is used on bicycles, there is no longer specific distinctiveness because the Kodak company does not sell bicycles. Expectation of some sponsorship of the bicycle company becomes the "abstract distinctiveness" which Shibuya argues is an essential element. ${ }^{64}$

Others require that the mark be "particularly striking" (tokubetsu kenchosei) ${ }^{65}$ This would be a standard even in excess of "exceedingly high brand identity." If this standard were used uniformly, a truly "famous" appellation would be rare. Additionally, in order to establish that a mark has been specifically diluted, some commentators require much more than the claim that the appellation was famous. ${ }^{66}$ They also require a positive determination regarding the appellation's originality, uniqueness, and impression. ${ }^{67}$ In other words,in addition to showing that the mark is famous, the plaintiff must establish that the junior user's goods or services are inferior. ${ }^{68}$

Overall, Japanese commentators conclude that in order to be protected by Article 21-2 of the UCPA, a mark has to be truly remarkable. It would seem that very few marks could carry this burden. This may, of course, be why the number of cases is so small. However, the cases that have been brought and succeeded in establishing fame involve appellations other than Japan's most famous marks such as Sony or Matsushita. Much lesser appellations have succeeded in establishing fame. Therefore, in reality, this "exacting standard" is not that exacting. That is, the mark must be remarkable but it does not have to be among the strongest marks in the world.

\section{Same or Similar Appellations}

In order for the provisions of Article 2-1-1 or 2-1-2 to apply, the second-comer's appellation must be the same or similar to the first-comer's ${ }^{69}$ However, because confusion is not required for an Article 2-1-2 violation, the element of similarity is given extra weight. ${ }^{70}$ Similarity is determined by comparing the sound, meaning, and appearance of the two appellations to determine if there is an apprehension that the two could be confused by a customer. ${ }^{71}$

${ }^{63}$ TATSUKi SHIBUYA, ChOMEIHYOJiBOYOKOI NitAISURU FuSEIKYOSOBOSHIHOJO NO KiSEI

[REGULATION OF FAMOUS APPELLATIONS USING THE UNFAIR COMPETITION PREVENTION ACT] 749 (1995).

${ }^{64} I d$.

${ }^{65}$ TAMURA, supra note 57, at 242. Tamura concludes that marks such as WORLD or PURE would be ineligible for protection under Article 2-1-2 of the UCPA.

${ }^{66}$ [No. Clear from subsequent footnote]Cite to these commentators

${ }^{67}$ ONO, supra note 49, at 298.

${ }^{68} \mathrm{Id}$.

${ }^{69}$ KANAI, supra note 40 , at 50.

70 YAMAMOTO, supra note 55, at 121.

${ }^{71}$ Aoyama Gakuin v. Shimizugaoka Gagakuen, 1815 HANREI JiHo 148 (Tokyo D. Ct., July 19, 2001). 
In determining similarity, the analysis should be broken down into three steps. The first step is to determine the essential elements of the plaintiff's appellation. The second step is to determine the essential elements of the defendant's appellation. The third step is to compare the essential elements of the two appellations. ${ }^{72}$ The other non-essential elements should be disregarded. ${ }^{73}$

Determining the essential elements of an appellation is done by omitting the portions of the appellation that are common, descriptive terms. The remainder should then be compared on an overall basis to determine if they are the same or similar in sound, meaning, or appearance. ${ }^{74}$

Although the statute only allows the holders of "famous" appellations to prevent the dilution if the second-comer's appellation is the same or similar to the famous appellation, courts seem willing to apply this in a manner that is not as strict as the black letter law seems to imply.

\section{REPRESENTATIVE CASES}

There are relatively few trademark dilution cases in Japan. ${ }^{75}$ Below is a description of some representative cases that would amount to precedent if Japan was a common law system. ${ }^{76}$

\section{A. Negurosu Denko KK v. Matsushita Denko $K K^{77}$}

Negurosu is an electronics manufacturer. Matsushita is a competitor but operates in a geographically different market. Matsushita adopted the shape of an electrical switch which had been manufactured and sold by Negurosu for quite some time. The question was whether this electrical switch could constitute a well-known ${ }^{78}$ good or appellation for purposes of Article 2-1-1 of the UCPA and as such form the basis of an injunction preventing the future sale and distribution of Matsushita's electrical switch.

${ }^{72}$ KANAI, supra note 40 , at 50.

${ }^{73} \mathrm{Id}$.

74 Id. at 53.

75 Because the term for dilution is not used in the statute, the cause of action is developing more as a common law tort. Therefore, courts occasionally make conclusions which they sometimes mislabel as dilution or reach dilution conclusions without labeling them as such. As there is no way one might search specifically for the latter, the number of dilution cases may actually be higher than portrayed here. Either way, the number of cases is small. See Miyawaki, supra note 22. Additionally, dilution has been held as grounds to refuse registration of a mark. See K.K. Heaven Corp. v. JPO, 1762 HANREI JiHo 130 (Sup. Ct., Jul. 6, 2001) (holding that, as PALM SPRINGS POLO CLUB was likely to dilute or freeride on POLO CLUB mark, it therefore violated Article 4-1-15 of the Trademark Law); Parfums Nina Ricci v. Madorasu K.K., 1040 HanRei TAimuZu 125 (Sup. Ct., July 11, 2000).

${ }^{76}$ As a civil law system, judicial precedent does not have the weight that it does in common law systems. See Kitagawa, supra, note 12. Even though de facto stare decis is developing in Japan, technically speaking, a subsequent court does not have to follow prior precedent. The reality, of course, is that most judges do now follow prior opinions. See HALEY, supra note 27, at 19-20.

77 Negurosu Denko K.K. v. Matsushita Denko K.K., 1819 HANREI JiHO 121 (Tokyo Koto Saibansho, May 31, 2002).

78 Actually, the court uses yet another term, shuchi, which is sometimes translated as famous. Shuchi is also a term used to describe when an appellation is well-known for purposes of Article 2-1-1. 
The Tokyo High Court held that the switch was a well-known good or other appellation, and ordered Matsushita to cease sales of the switch and pay damages in the amount of approximately $\$ 140,000$. Regarding the dilution claim, however, the Tokyo High Court stated as follows:

Matsushita argues that after it developed its product it used the same or similar shape on or in connection with the sale of a plurality goods sold to a plurality of consumers and that this situation continued for some time. In such a situation, if there was dilution, the product's shape would have ceased to be an appellation of source and it would no longer be a famous good or other appellation. To be sure, the type of dilution that Matsushita argues for is possible; however, in that case, it would not be sufficient to simply use the same product configuration on the same goods. In Matsushita's argument, actual sales for a period of time would be required before dilution could occur. In the case at bar, [Negurosu's products] have a limited share of the marketplace. They do not have an overwhelming presence in the marketplace and they have not been used for an extended period. Therefore, we cannot say that through dilution Negurosu's fame of its appellation has been diminished. ${ }^{79}$

Of course, this is not a traditional dilution case even though the court labels it as such. The court discusses "dilution" but analyzes this case under Article 2-1-1 of the UCPA which is not a dilution statute because it requires the plaintiff to show confusion.

Additionally, Article 2-1-1 says "causes confusion" (kondowo shojisaseru), and not "an apprehension of confusion" (kondono osore), which is used as the test for determining trademark infringement. ${ }^{80}$ The court here determines that the test for dilution should be an apprehension of dilution without recognizing that this case falls under Article 2-1-1, as the parties are in competition with each other.

In the United States, the Supreme Court requires a showing of actual dilution if the marks are not identical. ${ }^{81}$ Although Congress is doing its best to overturn this outcome, ${ }^{82}$ at least for the time being, the United States applies a more restrictive standard to dilution than Japanese courts apply. ${ }^{83}$

\footnotetext{
${ }^{79}$ Negurosu Denko K.K., 1819 HANREI JiHO at 130.

${ }^{80}$ See PORT, supra note 5, at 83. However, Japanese courts interpret this "causes confusion" as "apprehension that confusion will be caused." (kondoga shoshiruosorega aru). See Chanel ASA v. Sugimura, 986 HANREI TAIMUZU 181 (Sup. Ct., Sept. 10, 1999).

${ }^{81}$ Moseley v. V Secret Catalogue, Inc., 537 U.S. 418 (2003)

82 At the time of this writing, both the House and the Senate had passed bills that would amend the Lanham Act to make the standard for dilution claims a "likelihood" of dilution, not actual dilution. Trademark Dilution Revision Act of 2005, H.R. 683, 109th CONG. (2005); H.R. 683 EAS, Trademark Dilution Revision Act of 2006 (Engrossed Amendment as Agreed to by Senate).

${ }^{83}$ See E. \& J. Gallo Winery v. Spider Webs Ltd., 286 F.3d 270, 278 (5th Cir. 2002) (claiming that factors for likelihood of dilution include (1) blurring, or (2) tarnishment); Paco Sport, Ltd. v. Paco Rabanne Perfumes, 234 F.3d 1262 (2000) (asserting a dilution claim must prove (1) the trademark is truly distinctive or has acquired secondary meaning; (2) a likelihood of dilution either as a result of blurring or tarnishing; and (3) predatory intent); Hormel Foods Corp. v. Jim Henson Prods., Inc., 73 F.3d 497, 506 (2d Cir. 1996) (stating two elements for a dilution claim: (1) ownership of a distinctive mark and (2) a likelihood of dilution).
} 


\section{B. Tokyo Kyuko Dentetsu KK v. Takachi Noboru ${ }^{84}$}

In this rather odd case, an entertainer took the stage name of Takachi Noboru, represented by kanji characters that also read "kochi tokyu" or Tokyu Coach, and started performing in January of 1993. The plaintiff, Tokyo Kyuko Dentetsu, had used the appellation "Tokyu" since 1922. Its use resulted in that appellation becoming wellknown as part of the "Tokyu Group" set of marks. Based on Article 2-1-1 of the UCPA, the plaintiff sought an injunction to prevent the use of "Tokyu."

This case is ripe with Japanese puns and a little complicated to explain in English. The plaintiff, among other activities, operated a bus line called Tokyu Coach beginning in 1976. Another reading of the kanji characters representing the defendant's stage name is "kochi tokyu" or "Tokyu Coach," precisely the appellation used by the plaintiff for thirty years in different characters but resulting in the same pronunciation.

In an opinion that is said to feel the effects of the American dilution rationale, ${ }^{85}$ the Tokyo District Court found the appellations confusing and issued the injunction. As a general rule, for the appellations to be confusing, the parties must be in competition with one another. In a one-sentence conclusion, the court observed that it was not possible to believe that the parties were not in competition whatsoever (using this double negative) ${ }^{86}$ That is, because the court elected to use the double negative, it appeared like it was backing into this conclusion. The court clearly was bending over backwards to find competition when none really existed. As such, enough competition was shown for establishing the Article 2-1-1 cause of action, and the court does not have to address any dilution claim. ${ }^{87}$

The defendant claimed that he was engaged in parody and that he had come to rely on the acquiescence of the plaintiff. In response to this argument, the court stated:

However, Article 2-1-1 of the UCPA includes the right to prevent acts which amount to the free-riding of a well-known appellation whose value has been built up over time through unusual effort and the right to prevent the dilution of such well-known appellation. The defendant claims that he adopted the stage name so he would have a name that was distinctive and was easy to remember. However, the stage name is not a natural person's name, was not a name the entertainer was assigned at birth, and is a name he chose himself. As such, the conduct of promoting the stage name as a famous name using someone else's well-known appellation or a portion thereof is conduct ... . which the UCPA prohibits. There is no evidence that the plaintiff specifically allowed this conduct and no evidence that the plaintiff permitted this alleged custom. Therefore, we cannot employ the defendant's theory. ${ }^{88}$

${ }^{84} 1639$ HanRei JiHo 115 (Tokyo D. Ct., Mar. 13, 1998).

${ }^{85}$ See supra note 7 and surrounding text.

${ }^{86} 1639$ HANREI JiHO at 120.

${ }^{87} I d$. at 121.

${ }^{88} I d$. 
Although this analysis of dilution is repeated in the case a number of times, there is no discussion of what "dilution" might mean or what the parameters of the claim might be. The reader is left taking judicial notice that there is something called dilution (kishakuka) and, whatever it is, it happened in this case.

\section{Gibson Guitar Corporation v. Fernandes, K.K. ${ }^{89}$}

Gibson Guitar had sold its Les Paul design for decades in Japan. Fernandes and others adopted a similarly shaped electric guitar. Although Gibson prevailed on its claim of dilution in the United States, ${ }^{90}$ it failed in its attempts to enjoin Fernandes in Japan. Specifically addressing a dilution claim, the Tokyo High Court stated as follows:

Gibson's Les Paul guitar became well known among rock musicians and fans in Japan at least by 1973. We also have found above that this product configuration has come to represent Gibson's goods in the music industry. We have also found, however, that since at least 1973, Gibson's product configuration no longer represented the source or origin of any good. That is, for over twenty years more than thirty different brands were being used to sell guitars that resembled appellant's product configuration. During this period, Gibson admits that it took no steps to curb such use.

Therefore, it is impossible to say that consumers recognize the source of the Les Paul guitar simply by looking at the good. Thus, consumers would not remember the particular source of the guitars merely by looking at their shape.

On this point, Gibson argues that the dead copies being manufactured and sold in Japan were knowingly placed in the stream of commerce as dead copies. The manufacturers were passing these products off not as their own goods but as those of Gibson's. As such, these copies in the stream of commerce diluted Gibson's ability to use the product configuration to identify it as the source of the goods. Therefore, Gibson argues that the Les Paul shape lost its ability to identify Gibson as the source of its guitars.

The reality, however, is that the consumers recognize Gibson's guitar as one of the many copies and, as such, Gibson's guitar configuration does not function to identify a particular source of the goods; rather it now identifies many sources of the particular goods.

Gibson argues that consumers, upon being confronted with the Les Paul guitar, confuse the configuration of the goods with the source of the goods. This, however, simply is mistaken. Even if consumers, when confronted with the Les Paul guitar, know that it originated with Gibson,

\footnotetext{
${ }^{89}$ Gibson Guitar Corp. v. Fernandes, K.K., 1719 HANREI JiHo 122 (Tokyo High Ct., Feb. 24, 2000).

${ }^{90}$ Gibson Guitar Corp. v. Paul Reed Smith Guitars, L.P. 423 F.3d 539 (6th Cir. 2005).
} 
and even if they know a copy from the original, they do not believe that all guitars shaped like the Les Paul model originated with Gibson. ${ }^{91}$

Normally, a dilution cause of action arises when there is no competition between the parties. Here, although the parties were in direct, head-to-head competition in the marketplace, the court was detered. Instead, the court concluded that guitars shaped like the Les Paul guitar had become so popular in the marketplace and that the shape of the guitar had become generic. ${ }^{92}$ It appears that one lesson from this case is that dilution in Japan does not apply only to non-competitors. Because the UCPA in Article 2-1-2 is silent on the role of competition, this court presumed that it meant that the statute applied to competitors and non-competitors alike.

\section{Kobayashi v. Uesugi ${ }^{93}$}

Yoshinori Kobayashi is a famous and extremely controversial author of manga in Japan. Some manga are far more than mere conventional comic books. Some manga are serialized, sophisticated, and tell quite elaborate, mature stories. ${ }^{94}$ In keeping with Kobayashi's general persona, his manga are extremely controversial as well, such as including alternative histories of major events such as World War II. In the manga at issue in this lawsuit, titled "On Taiwan," Kobayashi depicts Taiwanese women begging to become Japanese soldiers' sex slaves in order to advance their social standing. ${ }^{95}$

Kobayashi is also a lead editor of a history textbook published by the Japanese Society for History Textbook Reform. ${ }^{96}$ When this textbook received Ministry of Education approval, riots broke out in China and Sino-Japanese relations reached their lowest level in post-war history. ${ }^{97}$ Kobayashi has an extremist, right-wing agenda, but he is also making record sales of his manga in Japan. ${ }^{98}$

In Kobayashi v. Uesugi, Uesugi wrote a book that criticized Kobayashi's manga "Gohmanism Sengen." "99 Uesugi's book was titled "Datsu Gohmanism Sengen."100

911719 Harei Jiho at 130-132. Translated in Kenneth L. Port, Japanese Intellectual Property Law in Translation: Representative Cases and Commentary, 34 VAND. J. TRANSNAT'L L. 847, 869 (2001).

921719 Harei Jiho at 132.

931702 Hanrei Jiho 145 (Tokyo D. Ct., Aug. 31, 1999), aff'd, 1831 Hanrei Jiho 107 (Tokyo High Court, July 31, 2003), aff'd, 1870 HANREI JiHo 15 (Sup. Ct., July 15, 2004).

94 The leading American commentator on manga is Salil K. Mehra of Temple Law School. See Salil K. Mehra, Copyright, Control, and Comics: Japanese Battles Over Downstream Limits on Content, 56 Rutgers L. ReV. 181 (2003); Salil K. Mehra, Copyright and Comics in Japan: Does Law Explain Why All the Cartoons My Kid Watches Are Japanese Imports?, 55 RUTGERS L. REV. 155 (2002).

95 See Christine Wawrynek, World War II Comfort Women: Japan's Sex Slaves or Hired Prostitutes, 19 N.Y.L. SCH. J. HuM. RTS. 913, 917 (2003).

${ }^{96}$ See www.tsukurukai.com. For a full text of chapters 4 and 5 of the book (in English), see www.tsukurukai.com/05_rekisi_text/rekishi_English.pdf.

${ }^{97}$ Norimitsu Onishi, In Japan's New Text: Lessons in Rising Nationalism, N.Y. TIMES, Apr. 17, 2005, at 4.

${ }^{98}$ Howard W. French, Japan's Resurgent Far Right Tinkers with History, N.Y. TIMES, Mar. 25, 2005, at 3.

99 Yoshinori Kobayashi, Shin Gohmanism Sengen (New Gohmanism Manifesto) serialized from 1996 to present. See also Yoshinori Kobayashi, On the War, Gohmanism SEngen: SPecial: SEnsoron (Special Declaration of Gohmanism) (1998).

${ }^{100}$ SATOSHI UESUGi, DATSU GOMANIZUMU SENGEN: KOBAYASHI YOSHINORI NO “IANFU” MONDAI (EX- 
"Sengen" means "manifesto" or "declaration." "Gohmanism" is more controversial, as Kobayashi coined the term. Literally, gohmanism means "arrogant-ism." Therefore, literally translated, Kobayashi's title means "Declaration of Arrogant-ism." Uesugi's book title means "Ex-Declaration of Arrogant-ism."

What this really means is that Kobayashi believes only that he is right (he seems, at least, to believe in his manga). The manga stands for the notion that one should be proud of being arrogant because it is only through this arrogance that people might actually see the "true" story of Japan's history. Gohmanism would have us believe that World War II was fought for the noble cause of freeing Asia from white colonists, that sex slaves in Korea and China thank their persecutors for improving their status in life, and that war crimes in the rape of Nanking did not happen. ${ }^{101}$ Essentially, this amounts to Japanese ultra-right wing extremist vacuousness.

Uesugi's book consisted of a panel by panel discussion of the accuracy of Kobayashi's claims. Uesugi pointed out the oddities as well as the outright myths perpetuated by the characters in Kobayashi's work. Kobayashi did not take kindly to being criticized; and consequently sued Uesugi for copyright infringement. Kobayashi claimed that "gohmanism" acted as an appellation of source, and the mark had become famous. ${ }^{102}$

The district court agreed with Kobayashi that "gohmanism" was a good or other appellation. They disagreed, however, that Uesugi had "used" that good or other appellation as required by Article 2-1-2 of the UCPA. On this point, the Tokyo District Court concluded:

"Datsu Gohmanism Sengen" is the title of the defendant's book. Since the defendant's book title includes the title of the plaintiff's work, we conclude that the defendant's use is a good or other appellation.

However, if one includes someone else's good or other appellation in explaining the goods, contents or characteristics of that person's work, we will not call such conduct the "use" of that good or other appellation or a similar appellation thereto [for purposes of the Unfair Competition Prevention Act].... The defendant's use of "Gohmanism Sengen" was to explain the content of his book. As such, we do not recognize the argument that the defendant used the plaintiff's appellation or an appellation similar thereto. ${ }^{103}$

If this case arose in the United States, the fair use doctrine would apply. ${ }^{104}$ Uesugi is making a nominative fair use of Kobayashi's appellation. ${ }^{105} \mathrm{He}$ is not using it in order

DeClaration of ARrogant-ISM: KobayAShi's “COMFORT WOMAN” PROBlem) (2002).

101 See generally Uesugi, supra note 101.

1021702 HANREI JIHO at 150.

103 Id. at 157.

104 See, e.g., KP Permanent Make-Up v. Lasting Impression I, Inc., 543 U.S. 111 (2004).

105 See, e.g., Brother Records, Inc. v. Jardine, 318 F.3d 900, 903-9 (9th Cir. 2003); Mattel, Inc. v. Walking Mountain Prods., 353 F.3d 792, 809-12 (9th Cir. 2003); New Kids on the Block v. News Am. Pub., Inc., 971 F.2d 302, 308-9 (9th Cir. 1992). 
to identify the source; he is using it to describe. Coupled with the "datsu" part of Uesugi's mark, this case is very similar to the "www.walmartsucks.com" cases ${ }^{106}$ under the Uniform Domain Name Dispute Resolution Policy ${ }^{107}$ in the United States.

Instead of a "fair use" analysis, this case focuses on whether including someone else's appellation in the title of a book can be considered "use" at all under Article 2-1-2 of the UCPA. Concluding that such conduct does not constitute "use" of a good or other appellation as required by Article 2-1-2, the court dismissed Kobayashi's claim. ${ }^{108}$

\section{E. K.K. JACCS v. Nihonkai Pakuto 109}

In this, Japan's first domain name case, the defendant had begun using the appellation JACCS in various places on its website and in its domain name, including registering the domain name "www.jaccs.co.jp." The plaintiff was a large, extremely well-known credit card company commonly called JACCS. The defendant claimed that it had legitimate commercial interest in the domain name because it stood for "Japan Association of Cozy Cradle Society." One product the defendant sold was toilet seats.

The case is an example of the use of Article 2-1-1 to enjoin the use of the domain name at issue under a dilution theory. The parties were obviously not in competition. As such, any injunction that might have issued in this case would be justified only under a dilution rationale. However, in enjoining the action, neither the District Court nor the High Court used the term "dilution" in their opinions.

The defendant claimed that the statute required the "use" (shiyo) of another's good or other appellation. Because "jaccs" merely appeared in its domain name, the defendant argued that it was not "using" the plaintiff's trademark in commerce. The court dismissed this argument and held that registering and having an active website that included the plaintiff's appellation was "use" of that appellation for purposes of Article 2-1-1.

\section{F. Levi Strauss v. Edwin Mfg. ${ }^{110}$}

In this case, the defendant's stitching in its " 501 " jeans around the rear pockets closely resembled the stitching of Levi' s " 505 " jeans. The court, quite accurately, found that this was both an infringement and a violation of Article 2-1-1, but not a violation of

\footnotetext{
106 See, e.g., Wal-Mart Stores, Inc. v. walmartcanadasucks.com, http://arbiter.wipo.int/domains/decisions/html/2000/d2000-1104.html (UDRP Panel Decision, Nov. 23, 2000) (judgment for respondent).

107 See Uniform Domain Name Dispute Resolution Policy, http://www.icann.org/dndr/udrp/policy.htm (last visited Mar. 31, 2006).

${ }^{108}$ Kobayashi, however, did prevail at trial on his claim that his moral right of integrity had been violated. The trial court ordered Uesugi to pay Kobayashi some $\$ 250,000$ in damages. Uesugi appealed this decision to the Tokyo High Court, Kobayashi v. Uesugi, 1831 HANREI JiHo 107 (Tokyo High Ct., July 31, 2003), and then to the Supreme Court, but did not prevail. Kobayashi v. Uesugi, 1876 HANREI JIHO 15 (Sup. Ct., July 15, 2004). On the cover of Uesugi's latest edition of his book, it reads "I beat Yoshinori $99 \%$ of the way. We have a judgment recognizing the [right] to quote from manga." SATOSHI UESUGI, DATSU-GOHMANISM SENGEN (EX-DECLARATION OF ARROGANT-ISM) (2002).

109 Reported only at: http://legal.lexisnexis.jp/jp/lngateway.dll?f=templates\&fn=defaultHome_JP.htm\&vid=Japan:10.1048/Enu (Nagoya High Ct., Sept. 10, 2001). The lower court opinion is translated in Port, supra note 91, at 883.

1101788 HANREI JiHO 103 (Tokyo High Ct., Dec. 26, 2001).
} 
Article 2-1-2. As the parties were clearly in competition, Article 2-1-1 was the more appropriate provision; however the court appropriately refused to label the defendant's conduct "dilution" (using the English term, not the Japanese term) even though the plaintiff had demanded as such. ${ }^{111}$ Therefore, it used the correct statutory provision to partially enjoin the defendant, but it used the wrong justification in its explanation.

\section{G. K.K. Daigyotsusho v. J-Phone Higashi Nihon K.K. ${ }^{112}$}

In this case, a company by the name of J-Phone started providing cellular telephone services in February 1997. ${ }^{113}$ Later that year, the appellant, K.K. Daigyotsusho, registered the domain name "www.j-phone.co.jp" with JPNIC (Japan Network Information Center-the equivalent of ICANN in the United States ${ }^{114}$ ). Even though JPhone's services preceded Daigyotsusho's advertisements by only a few months, the court found that J-Phone had advertised extensively in newspapers, television, radio, and magazines. ${ }^{115}$ The court found that its advertising campaign had reached all corners of Japan, sufficiently establishing that the plaintiff's product as well-known. ${ }^{116}$

Interestingly enough, the appellant found usages of " $\mathrm{j}$-phone" in New Zealand and Australia for telecommunication companies dealing with Japan. As such, the appellant argued that "j-phone" was an ordinary term for a Japanese telephone company. However, the lower court decided (there is no mention of this argument on appeal) that such use was negligible and done in a foreign country. Therefore, no weight was given to this argument at all. ${ }^{17}$

Finally in this case, the defendant argued that, as a result of the lower court's ruling that it could not use the appellation " $j$-phone" in a domain name or on its web site, the court had restricted the appellant's freedom of expression (hyogennojiyu) ${ }^{118}$ and the

\footnotetext{
111 Id. at 111.

112 Availible at
}

http://courtdomino2.courts.go.jp/chizai.nsf/Listview01/695F1B89FFD8F6D749256B2F00019773/?OpenD ocument (Tokyo High Ct., Oct. 25, 2001) (last visited April 22, 2006).

113 It actually began using the term "J-Phone" in 1994, but such use was under the auspices of a trade name of Tokyo Digital. See J-Phone Higashi Nihon KK v. KK Daigyotsusho, 1755 HANREI JiHO 43 (Tokyo D. Ct., Apr. 24, 2001).

114 See Internet Corporation For Assigned Names and Numbers, www.icann.org (last visited Mar. 31, 2006).

1151755 HANREI JIHO at 51.

116 Id.

117 This argument was brought in accordance with Article 11-1-1 of the UCPA which states as follows: "the act of using or indicating in a normally-used manner a common name of goods or business. . . [shall not be a violation of this Act]."

${ }^{118}$ Freedom of expression means something a little different than it does in the United States. No statute has ever been struck down for violating Article 21 of the Japanese Constitution, yet the Japanese Supreme Court seems intent on keeping freedom of expression as a central part of participatory democracy. See Ronald J. Krotoszynski, The Chrysanthemum, the Sword, and the First Amendment: Disentangling Culture, Community, and Freedom of Expression, 1998 WIS. L. REV. 905, 928-29 ("Although the Japanese Supreme Court generally has proven unwilling to interpose the constitutional guarantee of freedom of expression over legislative or executive acts, it has exhibited a strong and abiding appreciation for the importance of free speech in a participatory democracy."). See also Robert Trager \& Yuri Obata, Obscenity Decisions in the Japanese and United States Supreme Court: Cultural Values in Interpreting Free Speech, 10 U.C. DAVIS J. INT'L L. \& POL'Y 247 (2004) (arguing that the definition of obscenity in Japan is far broader than in the United States). 
holding was unconstitutional. ${ }^{119}$ In response to this claim, the Tokyo High Court stated that for a judge "[to] prevent unfair competition or the apprehension of unfair competition is only natural. Through the regulation of unfair competition, even if speech is restricted to some extent, that is not unconstitutional."120 Therefore, the freedom of speech argument was dismissed by the High Court. ${ }^{121}$

\section{H. Advance Magazine Publishers, Inc. v. Puropasuto ${ }^{122}$}

Finally, in a case that proposed to draw a distinction between the "well-known" provision from Article 2-1-1 of the UCPA and the "fame" provision from Article 2-1-2, the Tokyo District Court found VOGUE Magazine well-known but not famous and, therefore, not diluted under Article 2-1-2. ${ }^{123}$

The plaintiff was the publisher of a magazine whose name, although a common term in French that means "in style," was considered by the court to have acquired a distinctiveness as used on or in connection with the magazine. ${ }^{124}$ The defendant owned a condominium complex called "La Vogue Minami Aoyama."125

The Tokyo District Court held that even though the appellation "vogue" is a term in common usage in the United States and France, it was a rather distinctive appellation in Japan. As such, the court determined that the appellation was well-known for purposes of Article 2-1-1 of the UCPA. However, since the magazine's market was limited to those who read fashion magazines, the court held that it was not famous for purposes of Article 2-1-2 and, therefore, not diluted.

This was a case that is based on confusion in the broad sense. There was absolutely no competition between the plaintiff and the defendant. Any potential overlap between the two marks was only that rather wealthy, stylish people lived in the defendant's condominium. Such association was speculative at best and unstated in the case. Competition was presumed.

If anything, this was an Article 2-1-2 case. VOGUE was either both famous and diluted or neither. The creation and reliance on this middle standard by Japanese courts, when nothing to this effect is stated in the legislation whatsoever, muddled things interminably.

119 Although the court doesn't cite it, the Japanese Constitution, in relevant part, states as follows:

(1) freedom of assembly and association as well as speech, press and all other forms of expression are guaranteed;

(2) no censorship shall be maintained, nor shall the secrecy of any means of communication be violated.

KENPO, art. 21.

1201788 HANREI JIHO at 110.

${ }^{121}$ However, it was very creative lawyering to argue that the judgment itself worked as a restriction on a party's ability to express itself.

1221890 HANREI JiHO 127 (Tokyo D. Ct., July 2, 2004).

123 Id. at 141 .

124 Id. at 132.

125 Minami Aoyama is a very expensive residential neighborhood in inner Tokyo. Rents in this area commonly are around $\$ 15,000$ a month or more for a three bedroom, American-style apartment. See, e.g., http://www.kencorp.com/property/property.cgi. 


\section{WHY SO FEW CASES?}

There have been very few cases dealing with dilution in Japan. This is likely due to multiple factors. First, there are probably more cases than are reported, but even so that number is likely negligible. Second, the statute is vague and does not even use the word "dilution," thus Japan's civil law judges are not provided with much guidance. Third, the defensive trademark system, underutilized as it is, provides an alternative to dilution protection. Fourth, the theoretical understanding of trademark law renders the dilution claim superfluous.

\section{A. More Cases Than Meet The Eye}

One of the biggest problems researching Japanese trademark dilution is the fact that judges do not use a standardized term when they mean "dilution." It is convenient that the United States has adopted such a standardized term. In the United States, should one want to search all dilution cases, all one needs to do is search the word "dilution" in the Westlaw or Lexis databases. To be sure, that number will be large; however it will be inclusive and conclusive.

On the other hand, the Japanese courts do us no such favor. There is no standardized term in use by all Japanese judges for the concept of "dilution." Courts might refer to "dilution" in romanized letters, "dilution" in katakana (Japanese script indicating the word is of foreign origin), or the Japanese term for dilution (kishakuka); they might use the term "free rider" (furii raida) in katakana, the Japanese term that means "free rider" (tada nori), or many other possibilities. Most significantly, Japanese courts have also found dilution without naming it as such, usually under a theory of presumed confusion because they found confusion "in the broad sense."

Therefore, because Japanese courts do not use one standardized term for the cause of action, searching is extremely difficult. ${ }^{126}$ On the other hand, if one searches all of the above usages, one will most likely reveal most of the cases. That is, there are not hundreds of cases using yet some other indication other than the words given above.

Therefore, it is possible that there are other cases, but that number is not large. ${ }^{127}$

Another problem researching Japanese case law in general is the fact that there is no official reporter where all or substantially all opinions are collected. Rather, there are multiple "magazine" type publications that publish one or sometimes two trademark cases every two weeks. Therefore, it is possible that some trademark dilution cases exist but simply go unreported in any of the seven or eight journals where one would expect to find them. Although that is the case, there is a grand tradition in Japan to discuss important cases through study groups and the like on the faculty level. These professors closely watch, hear about, and discuss the various pending cases. It is, therefore, possible

${ }^{126}$ For example, if one searches "Article 2-1-2 of the UCPA", LexisNexis Japan turns up thirty-eight cases; if one searches "kishakuka and shyohyo" (dilution and trademark), sixty-five post-1993 cases are reported. By comparison, if one searches "Federal Trademark Dilution Act," Lexis U.S. reports 287 cases since 1996; if one searches "trademark dilution," over 1300 cases are reported. (Searches performed on Feb. 26, 2006.)

127 See, e.g., Chanel ASA v. Sugimura, 986 HanRei TAimuZu 181 (Sup. Ct., Sept. 10, 1999) (holding that "Chanel Snack" as used in katakana for a small drinking establishment is enjoined-no mention of "dilution"). 
that some unreported and important judicial decisions exist, but rather unlikely that a vast number of these decisions exist.

\section{B. Statute is Vague}

As indicated above, Japan has no statute that contains the word "dilution" or any of its derivatives in English or Japanese. Therefore, the fact that this law is to prevent something known as "dilution" is perceived intuitively from the fact that there is no other, more specific provision of the law that allows for this cause of action.

Additionally, Article 2-1-1 is also used to prevent a host of other acts considered to be "unfair" under the statute. As a result, Japanese courts cannot keep these causes of action straight. Japanese courts routinely interchange, with no discernable pattern, the causes of action that (1) prevent a well-known appellation from confusing use, and (2) prevent a famous appellation from any use by a third party.

Furthermore, Japanese courts do not seem to recognize the substantial difference between "causes confusion" and an "apprehension of confusion." Japanese courts sometimes require confusion in Article 2-1-2 cases - even though the statute only says "use" (shiyo) - and sometimes even presume confusion for purposes of Article 2-1-1 if the appellation is famous enough.

As such, it seems that it would be exceedingly difficult to predict when a client is likely to prevail in Article 2-1-1 or 2-1-2 cases, especially if one considers its famous appellation to be diluted by non-competing use. The scattered reasoning demonstrated by Japanese courts on the issue of dilution does not seem to provide the predictability one would expect from an otherwise highly developed legal system such as Japan's. ${ }^{128}$

Although other developed nations' dilution statutes do not necessarily use the term "dilution" either, ${ }^{129}$ they are far more specific. The courts in these other countries, outside of the United States, seem to have well-defined and consistent concept of dilution. ${ }^{130}$ Therefore, it seems that Japanese judges find something inherently flawed about the dilution rationale.

${ }^{128}$ To be fair, many US courts do not get this right either. Many require some form of confusion before they will grant an injunction. For example, New York courts used to require evidence of confusion even though the New York statute clearly dictates that dilution may be found regardless of confusion. Oddly enough, the Illinois courts have refused to find dilution if there is confusion. Therefore, New York courts required confusion while Illinois courts preclude dilution remedies when there is confusion. See generally James Burrough Ltd. v. Sign of the Beefeater, Inc., 540 F.2d 266 (7th Cir. 1976). Compare 765 ILl. Comp. StAT. AnN. 1040/0.01 (1986) with N.Y. GEN. BuS. § 368-d (McKinney 1992) (now repealed).

129 For example, the British statute reads as follows:

(3) A person infringes a registered trade mark if he uses in the course of trade a sign which

(a) is identical with or similar to the trade mark, and

(b) is used in relation to goods or services which are not similar to those for which the trade mark is registered, where the trade mark has a reputation in the United Kingdom and the use of the sign, being without due cause, takes unfair advantage of, or is detrimental to, the distinctive character or the repute of the trademark.

1994 UK Trade Marks Act [1995], § 10(3). See also David S. Welkowitz, Protection Against Trademark Dilution in the U.K. and Canada: Inexorable Trend or Will Tradition Triumph?, 24 HASTINGS INT'L \& COMP. L. REV. 63, 84-88 (2000).

${ }^{130}$ Wagamama Ltd. v. City Centre Rests., [1995] IP \& T Digest 21 (U.K.); Mars UK Ltd. v. Burgess, [2004] W.L. 1476759 (Ch. D.). 
The American instinct is to dismiss Japanese judges as uninformed or ignorant. This conclusion is fostered by the ambiguity of the UCPA itself. However, I categorically deny the notion that Japanese judges are just missing the boat. The Japanese judiciary is a well-educated, well-trained group of career jurists. They are not political appointees like United States federal judges. They enter the judiciary upon graduating from the Legal Research and Training Institute. ${ }^{131}$ District and Appellate Court judges have had no other job in their life other than as a judge. They are supported by a very well-paid and motivated research and support staff. ${ }^{132}$ The idea that Japanese judges are just uninformed or ignorant of trademark dilution is simply not believable.

\section{Defensive Mark Registration System is Not Used Either}

Under the defensive mark registration system, ${ }^{133}$ "widely recognized" trademarks can be registered ${ }^{134}$ to protect identified goods or services ${ }^{135}$ other than those listed in the original registration. This system does not exist in the United States. Additional goods or services need not be similar to the original goods or services, and the registrant need not have any use for these additional goods or services nor any intent to use the mark on these additional goods or services. ${ }^{136}$ The requirements are only that the mark be "widely recognized by consumers" (hiroku ninshiki sareteiru) and that there be an apprehension of confusion (kondo no osore) if the mark is used on these additional goods or services by a third party. ${ }^{137}$ It is not difficult to see why this has been referred to as a "super registry." 138

Whether a trademark is "widely recognized" (or "famous") ${ }^{139}$ for purposes of a defensive mark application is determined by referring to Guidelines for Examination of Trademarks published by the Japanese Patent Office. According to this manual, the determination of a registered trademark's degree of fame is made by referring to the following items:

(1) Duration and area of use;

(2) The range of goods on which the mark is used;

(3) Extent of advertisement used or other methods of publicizing the mark;

(4) The nature of the user's business and scale of use of the mark; and

\footnotetext{
131 Haley, supra note 27 at 43.

132 Id. at 114-18.

133 See generally SHOEN ONO, SHOHYOHO GAISETSU [OUTLINE OF TRADEMARK LAW] 166-71 (1999).
}

It might be somewhat telling that in this, a primary source of Japanese trademark law, the author elects to only give the defensive mark system some five pages of coverage.

${ }^{134}$ Trademarks are registered in Japan just like any country. The applicant fills out a form, pays the proscribed fee, and, unless there is a statutory reason to deny the registration, such as if the mark is generic or merely descriptive, the Japanese Patent Office issues a registration certificate. See generally Japanese Trademark Law, Law No. 47 of 1959. See also PORT, supra note 5.

135 "Identified Goods or Services" herein refers to those specific goods or services named in the trademark application. The trademark registration is only valid as used on those specific goods or services and on similar goods and services.

136 Yasuichi Arao, Bogohyoshoseido nitsuite [On the Defensive Mark System], 138 SHOJIHOMU KENKYU 10 (1959).

137 Trademark Law, Art. 64.

138 Suzuki, supra note 5, at 171.

139 For defensive mark applications, "widely recognized" (hirokuninshikisareta) now becomes synonymous with "famous" (chomei). See ONO, supra note 133, at 130. 
(5) Office. $^{140}$

The amount of recognition the mark already enjoys within the Patent

Not surprisingly, most likely because the strict nature of the requirements to prove a mark is widely recognized, ${ }^{141}$ very few marks have been registered as defensive marks. Furthermore, the JPO and courts seem overly restrictive in granting defensive mark registrations.

The JPO and Japanese courts require that the registration of the mark a defensive mark must be "identical" to the primary registered trademark. ${ }^{142}$ Therefore, the Tokyo High Court affirmed an examiner's rejection of "Mercedes-Benz" as a defensive mark application for string, rope, or netting because it was not identical to its principal mark, Mercedes-Benz as registered for use on automobiles. That is, the marks do not share the same font and the primary registered trademark is in all upper case letters. ${ }^{143}$ The court held that "if the plaintiff [Mercedes-Benz] wanted to prevent the use of its mark in this fashion, they ought to elect to register the mark as an associated trademark. Attempting to interpret this as a defensive mark registration is absurd (sujichigai)."

Given the specific language of the Trademark Law, ${ }^{145}$ it is difficult to determine who is being absurd. It appears on the surface that this is a perfect example of a famous mark that deserves defensive mark registration status. However, the court also read strictly the requirement that there be some apprehension of confusion as to source in the class of goods under which defensive mark registration is sought. Because there was none here, the court found the associated mark doctrine to be the best source of protection for Mercedes-Benz.

The JPO also denied 3M Corporation's defensive mark registration application for its SCOTCH trademark, which is registered in Japan for use on tapes and other adhesives, to prevent its use on kitchen utensils and other kitchen products. The Examiner claimed that there was no apprehension of confusion because 3M used SCOTCH in upper case letters on some goods, while on others the mark appeared in lower case letters, and therefore the marks were not identical. ${ }^{146}$

140 KANJI KUDO, SHINSA KIJUN NO KAISETSU (Explanation of Trademark Examination Guidelines) (1996) at 306.

141 Zentaro Kitagawa, Doing Business In JAPAN, at 3.01[3][c].

142 See Trademark Law, Art. 64.

143 Daimler Benz AG v. JPO, 1326 HANREI JiHo 145 (Tokyo High Ct., July 27, 1989).

144 Id. at 147. Mercedes' contention was absurd, of course, because the statute also requires some likelihood of confusion. The associated mark system has now been abolished. See PoRT, supra note 5, at 105. See also Kazuo Morioka, Shyohyoho Oyobi Fuseikyosouboshihoni iu "Juyoshanoaidani Hiroku Ninshikisareteiru” no Imi [Interpretation of Trademarks “Well Known Among Consumers”], 37 PAT. STUDIES 17 (2004) (discussing the fact that the term "well known" is used seven places in the Trademark Law and the UCPA and concluding that when used in regard to defensive marks, it means something different than when used in Article 2-1-1 of the UCPA. In defensive marks, "well known" now means nationwide use, not regional or local use).

${ }^{145}$ Trademark Law, Art. 64 states as follows: "The owner of a registered trademark may obtain a defensive mark registration of a mark identical with the registered trademark with respect to goods or services with which and apprehension of confusion exists. . ." Apparently, identical, for once, really means "identical."

1461563 HANREI JiHo 134 (Tokyo High Ct., Jan. 30, 1996). See also, Kazuo Morioka, Shyohyoho Oyobi Fuseikyosouboshihoni iu “Juyoshanoaidani Hiroku Ninshikisareteiru” no Imi (Interpretation of Trademarks "Well Known Among Consumers"), 37 Patent Studies 17 (2004) (discussing the fact that the term "well known" is used seven places in the Trademark Law and the UCPA and concluding that when 
However, the Tokyo High Court held that SCOTCH was, indeed, well-known and reversed the JPO's decision. The court determined that the appropriate standard should include an analysis of the trademark as it is actually used. If consumers would presume that the principal mark and the mark that is subject of a defensive mark application identify the same source, then the mark should be considered identical and appropriate for defensive mark registration. ${ }^{147}$

The defensive mark system is already in place for a "famous" registry, making Article 2-1-2 somewhat superfluous. ${ }^{148}$ This super registry afforded by the defensive mark system is the precise mechanism third party users of appellations might rely upon to determine when someone else's appellation is famous. Of course, this is only analogous to a super registry for marks subject to dilution. However, because Japan has such a registry in place for famous marks for purposes of the defensive mark system, the leap to a registry for appellations subject to dilution protection is not that great.

The defensive mark system is somewhat redundant to dilution protection because it already provides an avenue by which registrants of famous marks might find additional protection. Of course, it applies only when there is an apprehension of confusion and therefore is not precisely responsive to a traditional dilutive setting; however. Because Japanese courts are inconsistent in the requirement of competition, or not, one would expect a Japanese attorney zealously representing the interests of his or her clients to be very interested in the defensive mark system when the client is the owner of a famous mark.

However, all that being the case, the defensive mark system is a perfect example of how countries could require registration on a super registry before dilution protection is granted. ${ }^{149}$ Because the Japanese have the defensive mark system already in place, it is not as much of an extension to require such a registration of anyone claiming protection under Article 2-1-2 of the UCPA.

This system is drastically underutilized. ${ }^{150}$ It is underutilized because it provides protection that few actually desire. The system requires the would-be defendant's mark to be identical to the would-be plaintiff's mark. Defendants do not often adopt identical copies of famous marks. Of course, if they do and they do it with the intent to deceive,

used in regard to defensive marks, it means something different than when used in Article 2-1-1 of the UCPA. In defensive marks, "well known" now means nationwide use, not regional or local use.).

147 See Morioka, supra note 146.

148 In fact, the JPO now maintains a searchable database in English (see http://www1.ipdl.ncipi.go.jp/chomei/search_e.cgi?login\&1127886096828) and in Japanese (http://www1.ipdl.ncipi.go.jp/chomei/search_j.cgi?login\&1127885941593) for famous marks. This database is maintained by the JPO without requiring any proof on behalf of the entrants.

149 See Kenneth L. Port, The Congressional Expansion of American Trademark Law: A Civil Law System in the Making, 35 WAKE FOREST L. REV. 827, 894 (2000). For a detailed analysis of the pros and cons of adopting a super registry in the United States, see Lars S. Smith, Implementing a Registration System for Famous Trademarks, 93 TRADEMARK REP. 1097, 1106-07 (2003), and Kenneth L. Port, The Trademark Super Registry: A Response to Professor Smith, 94 TRADEMARK REP. 881 (2004).

${ }^{150}$ Registrations per year of defensive marks:

\begin{tabular}{|c|l|l|l|l|}
\hline 2000 & 2001 & 2002 & 2003 & 2004 \\
\hline 156 & 103 & 121 & 143 & 60 \\
\hline
\end{tabular}

Source: JPO at http://www.jpo.go.jp/shiryou/toushin/nenji/nenpou2005_pdf/toukei/02-05_02.pdf. As this table indicates, applicants are not busting down the JPO's door to get at the defensive mark registration system. Only sixty were registered in 2004. 
the defensive mark system is there to help prevent such conduct. However, this probably does not happen very frequently. ${ }^{151}$ This defensive mark system would help Fuji Film prevent the use and registration of Fuji for bicycles, if they registered for a defensive mark. However, as there were only sixty defensive mark registrations in all of Japan in 2004 , it appears that this kind of conduct is rare.

The system also provides enough time for the would-be plaintiff to file for the trademark application for a defensive mark, rather than just initiating a lawsuit. Nearly all of the Article 2-1-2 cases reviewed for this article were ripe for a defensive mark registration. Rather than registering, the plaintiffs elected to file for an injunction and damages under Article 2-1-2 of the UCPA.

Therefore, there are redundancies built into the Japanese system. These redundancies themselves may be providing a chilling effect on the frequency with which lawsuits are filed under Article 2-1 of the UCPA. The existence of the defensive mark system provides an alternative route for protecting famous marks.

\section{Dilution is Superfluous in Japan}

Dilution protection, as defined herein, is not a surprising expansion of the law, as it was in the United States. ${ }^{152}$ Courts in Japan frequently engage in protecting trademarks even without a showing of competition between the parties. They do this by calling it "confusion in the broad sense of the term."153

Japanese courts generally approach confusion as "narrow" (kyogi) confusion and "wide" (kogi) confusion. ${ }^{154}$ That is, Japanese courts consider narrow confusion to exist when two parties are in direct competition. Confusion in the wider sense of the term $(k o g i)$ is used to prevent conduct that may also be prevented under a dilution rationale. ${ }^{155}$

Therefore, when "Mitsubishi Building Company" uses the appellation "Mitsubishi," it is not unreasonable to believe that all companies named "Mitsubishi" are related, even though at that time, the larger and famous Mitsubishi did not have a "building" company in its quiver. ${ }^{156}$ Also, when the defendant used the appellation "Womanpower" for temporary secretarial services, they were deemed to be in competition with "Manpower," even though there was no direct evidence that this was, in fact, the case. ${ }^{157}$ The court stated that there was an apprehension that people would believe Womanpower was a subsidiary of Manpower and, even though there was no

151 This is the true dilution rationale that promoters argue for in the United States.

152 Maureen A. O'Rourke, Fencing Cyberspace: Drawing Borders in a Virtual World, 82 MINN. L. REV. 609, 672 (1998); David S. Welkowitz, Oh Deere, What's to Become of Dilution? A Commentary on the New Federal Trademark Dilution Act, 4 UCLA ENT. L. REV. 1 (1996).

${ }^{153}$ Chanel ASA v. Sugimura, 986 HANREI TAIMUZU 181 (Sup. Ct., Sept. 10, 1999). This all probably started with Marutake Shoji, K.K. v. NFL Properties Inc., 530 HANREI TAIMUZU 97 (Sup. Ct., May 29, 1984). In that case, the NFL had licensed to a Japanese corporation the rights to thirty names of its teams. That company sub-licensed nineteen other companies to manufacture sweaters, shirts, and neckties. Marutake Shoji had used the names of the football teams on lockers. The court found this to be confusion in the broad sense of the term.

${ }^{154}$ See, e.g., Marutake Shoji, K.K. v. NFL Properties Inc., 530 HANREI TAIMUZU 97 (Sup. Ct., May 29, 1984).

${ }^{155}$ The number of these cases is quite large. A search of www.legal.lexisnexis.jp turned up thirty-five cases.

${ }^{156}$ Mitsubishi Kensetsu v. Mitsubhishi Jisho K.K, 364 HANREI JiHo 28 (Osaka High Ct., Jan. 30, 1964).

1571094 HANREI Jiho 107 (Sup. Ct., Oct. 7, 1983). 
direct evidence of their competition in the marketplace, the court deemed them in competition. In both of these representative cases, the court simply deemed the parties to be in "competition" with each other even though there was no direct evidence to that alleged and important fact. ${ }^{158}$

The holding in Japanese Womanpower K.K. v. Manpower Japan K.K., seems to allow for a plaintiff to "bridge the gap." 159 That is, although the defendant may not be in competition with the plaintiff at the time of the case, there is reasonable expectation that they may actually be in competition in the future. Instead of using this potentially more appropriate analysis, however, the courts in these cases merely deem competition to be present. Worse yet, if the holder of a famous mark can be presumed to be in competition with anyone who might come along, then there is really no need for a dilution statute at all and it is not surprising in the least that Article 2-1-2 is underutilized.

\section{CONCLUSION}

Given the overall circumstances of trademark protection in Japan, it is not surprising that there are very few traditional "dilution" cases. The statute is too vague to be of any real guide - it does not even mention the word "dilution." The statute allows an injunction and damages in the event that a famous mark is used and does not require the plaintiff to establish confusion. While this cause of action sounds like dilution, it would help Japanese courts immensely if that word was used, so that the Japanese legislature's intent could be more easily determined.

Judges in Japan do not stick to an establish vocabulary when addressing dilutionlike cases. They use terms like "free-riding" or other terms to describe what would be a dilution case if it were raised in the United States. This lack of a standardized vocabulary leads to further confusion regarding the cause of action and makes it appear that even fewer cases are raised.

The nature of trademark infringement also makes dilution redundant. The defensive mark system in Japan provides an alternative to trademark owners who desire to protect their famous marks from use by non-competitors on non-competing goods. However, even this system, in place in Japan since $1959,{ }^{160}$ is underutilized.

The other redundancy regards the trademark right itself. In Japan, the trademark right can be conceived of "broadly." Under the so-called broad conception, confusion and competition are not necessary. When the mark is famous, Japanese courts sometimes will presume confusion.

The state of confusion over this cause of action and the resulting diminished number of cases may be interconnected. Through this confusion, Japanese judges either intentionally or intuitively apply a brake to the application of dilution law in Japan.

On the other hand, perhaps the apparent lack of dilution in Japan is not an aberration. Perhaps it is not that there is no dilution in Japan; perhaps the issue is

\footnotetext{
${ }^{158}$ See, e.g., 364 HANREI JiHO at 29.

159 "Bridging the gap" is the term used in the United States to explain a situation where there may not currently be competition between the parties, but that competition is either planned or is a natural extension of the plaintiff's goods or services. Polaroid Corp. v. Polarad Elects. Corp., 287 F.2d 492 (2d Cir. 1961), cert. denied, 368 U.S. 820 (1961).

${ }_{160}$ See Japan Trademark Association, http://www.jp-ta.jp/meeting/001/021024.html (last visited Mar. $31,2006)$.
} 
whether there is really much actual dilution anywhere. Perhaps it is the United States that is the aberration. Maybe, it is just that, in the United States, we see dilution everywhere and over utilize the Federal Trademark Dilution Act.

One way or the other, Japanese trademark dilution law is in a state of confusion and disarray. Such confusion does not help in developing a coherent and predictable body of law. The rest of Japanese trademark law is highly predictable and certainly coherent. That trademark dilution law is not stands out as an oddity. 